Grant Period: $9-30-88$ to $3-29-92$

Grant Amount: $\$ 190,916$

Date: March 29, 1992

\title{
DISCLAIMER
}

This report was prepared as an account of work sponsored by an agency of the United States Government. Neither the United States Government not any agency thereof, nor any of their employees, makes any warranty, express or implied, or assumes any legal liability or responsibility for the acessacy, completeness, or usefulness of any information, apparatus, product, or process discloped, or represents that its use would not infringe privately owned rights. Reference herein to any specific commercial product, process, or service by trade name, trademark, manufacturer, or otherwise does not necessarily constitute or imply its endorsement, recommendation, or favoring by the United States Governmut or any agency thereof. The views and opinions of authors expressed herein do not necessarily state or reflest those of the United States Government or any agency thereof. 


\section{TABLY OF CONTENTS}

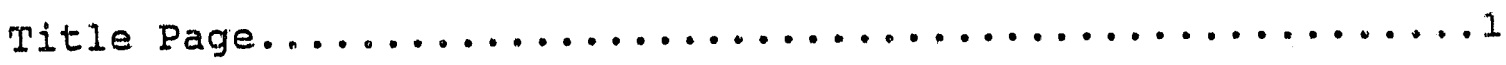

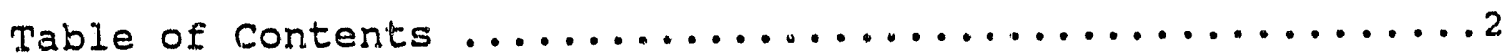

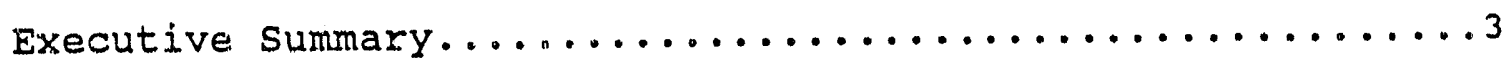

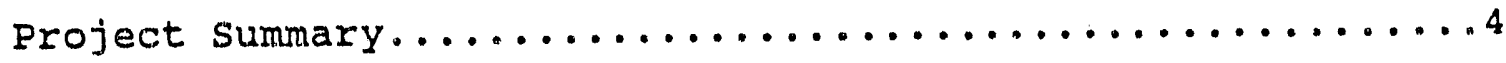
Introduction $\ldots \ldots \ldots \ldots \ldots \ldots \ldots \ldots \ldots \ldots \ldots \ldots \ldots \ldots \ldots \ldots \ldots \ldots$ Investigative Approach and Research Results.............

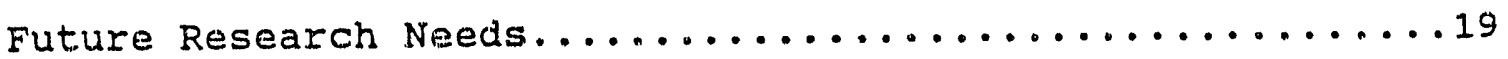
Materials \& Methods Use in This Research .................

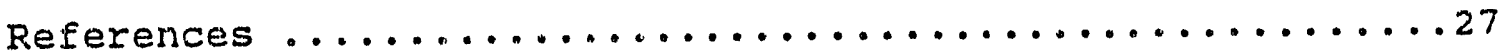
Papers and Presentations Resulting From the Research.....33 


\section{Executive summary}

Huge world reserves and the low caloric value of lignite coal strongly suggests a need to develop alterrative technology that can make better use of this fossil fuel. source. Its close structural similarity to lignin and high oxygen content are indicative of promising prospects for bioprocessing lignite coals. It is, however, certain that in order to convert lignite coals into liquid fuels, gases or chemical feedstock, the macromolecular structure of the coal must be broken down into low molecular weight fractions prior to further modification. Our research focused on this aspect of coal bioprocessing.

We isolated, characterized and studied the lignite coaldepolymerizing organisms streptomyces viridosporus T7A, Pseudomonas sp. DLC-62, unidentified bacterial strain DLC-BB2 and Gram-positive Bacillus megaterium strain DLC-21. In this research we showed that these bacteria are able to solubilize and depolymerize lignite coals using a combination of biological mechanisms including the excretion of coal solublizing basic chemical metabolites and extracellular coal depolymerizing enzymes. 


\section{Project summary}

The initial hypothesis upon which this research was based was that microorganisms, particularly strictly anaerobic bacteria, would be able to metabolize and thereby biotransform lignite coals in ways that would completely or partially biotransform the coal into higher value liquid fuel products. By use of anaerobic bacteria it was thought that the biotransformations would be largely reductive, as opposed to oxidative. Thus, the Iiquid products generated would not be reduced in caloric fuel value as compared to the starting coal. During the course of research numerous bacteria were isolated and characterized for their. abilities to biotransform coal and coal substructure model compounds. The isolates eventually chosen for detailed study turned out to be aerobic bacteria which nonoxidatively both solubilized and depolymerized the coal. Thus, the orginal objectives of the research wer met, but with aerobic instead of anaerobic bacteria. The mechanism by which selected of the bacteria solubilized lignite coals were determined. This mecharism involved the excretion of basic chemical metabolites which accumulated in the growth medium. These metabolites, in turn, acted chemically to solublize the coal. In addition, the mechanisms by which selected of the bacteria depolymerized solubilized lignite coal polymer were determined. This mechanisms involved the excretion of extracellular coal depolymerizing enzymes. Follow-up studies showed that the specific types of enzymes involved appeared to be extracellular peroxidases, esterases, and possibly etherases. The results show 
that bacteria can be used to beneficially transform coal, by solublizing and depolymerizing the coal into lower molecular weight products that have not be extensively oxidized as a result of the microbial metabolism. Future work should focus research aimed at optimizing the biodepolymerization process, developing bioreactor configurations for scaling up the biodepolymerization process, and understanding the basic enzymatic biochemistry of the coal depolymerizing enzyme reactions. 


\section{Introduction}

Coal constitutes the largest portion of the world's fossil fuel reserve. The current level of world coal production is estimated to be 5.2 billion short tons per annum, with the largest producers being china (1054 million short tons), U.S.A. (950 million short tons), Soviet union (865 million short tons). and United Germany (556 million short tons). 1 of these major producers, the United states, Soviet union and china have by far the largest recoverable world coal reserves-29\%, 26\%, and $11 \%$ respectively. ${ }^{2}$ Although coal represents a significant world fuel reserve, not all deposits are of high economic importance at present.

Because of its variance in chemical composition and corresponding degrees of economic importance, coal is classified by rank into four categories: starting with the least degree of coalification, these are lignite, subbituminous, bituminous, and anthracite coals. Bituminous and anthracite are classified as high-rank coals because of their high caloric value; Lignite and subbituminous, on the other hand, are classified as low-rank, brown, or soft coals because of their low caloric value. Highrank coal deposits are estimated to be 6,900 billion tons- out of which 993 billion tons are recoverable under current mining techniques. Confirmed world reserves of low-rank coal are 6,500 billion tons- out of which 576 billion tons are recoverable. 1,3 Low-rank coals are characterized by low aromaticities, small aromatic ring clusters, and abundant aliphatic and heteroaromatic structures. The low calorific value (around 11,500 Btu/lb), due 
to low carbon, and high oxygen and moisture contents, makes lowrank coals unsuitable for power production. 4 Low-rank coals also contain high levels of alkali and alkaline earth elements. In fact, these inorganic constituents are the cause of fouling, agglomeration, and slagging in conventional processes. 5 such undesirable characteristics and lack of world supply strongly suggest that low-rank coals should be Iiquefied, gasified, or converted into chemical feedstocks. Biological processes may be useful for carrying out such conversions. ${ }^{6-11}$

As early as 1908 researchers were experimenting with the microbial utilization of coal, 12 but it was chiefly the work published by Cohen and Gabrielle in 1982 that stimulated present interest in coal bioprocessing. ${ }^{19}$ They were the first to report the formation of watex-soluble products by the action of the wood-rotting Basidiomycete fungi Trametes versicolor and poria monticola on low-rank coals. Since then, there have been tremendous interest in and research efforts devoted to utilizing fungi, 19-40,50,52 actinomycetes ${ }^{28,45-52}$ and bacteria, 12-18,29,5260 for coal bioprocessing.

\section{Investigative Approach and Research Results \\ Overal1 Research Results}

In our efforts to utilize low-rank coals for energy and chemical feedstock production ${ }^{48}$, we isolated several aerobic Gram-negative and Gram-positive bacterial cultures which depolymerize water-soluble lignite coals into low molecular weight products.55-60 Production and involvement of 
extracellular enzymes in lignite bio-depolymerization was proven by HPLC analysis. 57-60 we also characterized the extracellular enzymes in the culture supernatants of Pseudomonas strain DLC-62 and streptomyces viridosporus T7A. 59 The enzymes in the case of Pseudomonas strain DLC-62 consisted primarily of peroxidases (two isoforms) and esterases (five isoforms). Etherases were probably also present, but their existence was not uneugivocally shown. The two peroxidase isoforms were constitutively expressed. When partially purified, the esterases from periplasmic, cytoplasmic, and membrane fractions of the cells showed no coal depolymerizing activity. Unpurified crude enzyme preparations, on the other hand, containing both esterases and peroxidases did show coaldepolymerizing activity. The results with 3 day mineral saltspeptone + coal cell-free culture filtrates, particularly in case of Pseudomonas sp. DLC-62 and unidentified strain DLC-BB2, clearly-suggested free radical formation which could be due to the presence of peroxidase, laccase or multiple cytochrome p -450 type of enzymes. It seems quite reasonable to expect these bacterial cultures to attack low-energy requiring bonds like ether and ester and bridged methylene groups rather than high energy carbon-carbon bonas. Resonance stabilization of phenolic radicals would certainly be responsible for lowering the activation energy requirea to cleave high-energy bonds inside the coal polymeric structure. Indirect oxygenation-either by direct action of oxygenases, or by oxidative or hydrolytic cleavage of ether and ester linkages must have been responsible for increasing the polarity of hydrophobic substrates like 
lignite coal polymer. Peroxidases and ligninases have been implicated in the depolymerization of lignin and synthetic azodyes. 41

our research group has been involved in studies of the biodegradation of lignin for over fifteen years, and based upon our knowledge in that area, we noticed that the depolymerization mechanisms of lignin and lignite, and the nature of the enzymes involved, seemed to be similar.. It is fair to say that coal biotransformation and bioconversion will not be technically and economically feasible until and unless the coal macromolecular structure is broken down into low molecular weight fractions for further utilization or modification. Therefore, coal biodepolymerization seems to be the crucial step in efficient biogasification, bioliquefaction, biosolubilization and biological coal beneficiation. our research showed that bacteria possess the ability to significantly depolymerize lignites. Our future goal should be to understand and develop precise bioreactor configurations, to further define the enzymatic mechanism responsible for the lignite depolymerization, and to increase the level of lower molecular weight profucts produced from iignite in order to provide economically and technically feasible processes for the production of liquid and/or gaseous fuels.

Coal biotransformations can be grouped into four categories: solubilization, depolymerization, gasification, and liquefaction. In solubilization, coal is microbially converted into watersoluble polymeric material; the product may or may not have been 
significantly depolymerized when compared to the starting coal. In depolymerization, coal which has been solubilized microbjally or chemically becomes significantly reduced in average molecular weight as a result of microbial action. This requires cleavage of macromolecular bonds in the coal. In gasification, the coal is microbially converted to methane and carbon dioxide gas. In this case, the starting coal may be solid, liquid, polymerized, depolymerized, or modified previously chemically or microbially. In liquefaction, coal is converted to a water-insoluble liquid-a conversion that probably requires both depolymerization and reductive transformation of the coal polymer.

over the past nine years several research groups have reported the solubilization of low rank coals by the following fungi: Acremonium,sp. 22 Aspergillus sp.20,23, Candida sp.20,28,33-35,37 (strain ML-13),21,23,51 Coriolous versicolor $27,28,37,51$ (also known as Polyporous versicolor $19,25,26$ and Trametes versicolor $23,30,31,36$ ), Cunninghamella sp.28,29,37,51, Ganoderma applanatum,51 Heterobasidion annosum, 28 Mucor sp. 20 , Paecilomyces sp.20,23,3234, Penicillium sp. 20,22,28,29,36,37,50 (P. waksmanii ML$20^{21,23,51}$, Percniporia subacida, 28 Perenniporia tephropora, (Fomes lividus), 51 Phanerochaete chrysosporium, 24,28,29, $37,39,40,51$ Pleurotus ostreatus ${ }^{51}$ Poria monticola19,23 (also known as Poria placenta ${ }^{28}$ and oligoporus placentus), Polyporous dryophilus var. vulpinus, 28 Pycnoporus cinnabarinus, 51 Rigidoporus ulmarius, 51 sporothrix sp.23, and Xylaria hypoxylon.51 Although certain of these reports have suggested 
the possible involvement of oxidative extracellular enzymes in the coal solubilization process, others have been strongly indicative of non-enzymatic coal-solubilizing secondary metabolites. $11,30,31$

Fredrickson et al. ${ }^{30}$ isolated a low molecular weight (5001000 dalton) extracellular metabolite from cultures of the fungus Trametes versicolor, which appeared to be responsible for lignite coal-solubilizing activity. The compound was thought to be desferal mesylate, a hydroxamate siderophore-like compound. In contrast, cohen et al. 31 have isolated a different coalsolubilizing metabolite from culture supernatants of $T$. versicolor (ATCC-12679). After purification and crystallization they characterized the solubilizing agent as ammonium oxalate. It seems rather plausible that after the uptake of iron and other transition metals by the siderophores and chelators, a disruption of charge-transfer interactions 42 between the coal molecule may be the real fungal coal solubilization factor.

Iinehin ${ }^{36}$ characterized the biosolubilization of a leonardite coal and a pre-oxidized IIlinois \#6 coal by two fungi, Trametes versicolor and Penicillium species. He found that biosolubilization was oxidative and that the biosolubilized product was slightiy soluble in organic solvent and had a molecular weight below 20,000 daltons. Interestingly, as the coals were incubated with fungi, more coal becarne water-soluble over time, and the average molecular wt. of the soluble products progressively increased. 
stewart et al. 37 recently studied a penicillium sp. strain RWL-5 which degraded an air-oxidized bituminous coal and caused erosion of the coal surface. The authors also believed that depolymerization of the coal occurred during biosolubilization. This was suggested by a comparison of the molecular weights of the biosolubilized product (1000 dalton) a the base-solubilized product (6000 dalton).

Fakoussa et al. 38 isolated and examined Chaunopycnis alba for the production of coal-solubilizing enzymes. They associated the ability of this fungus to solubilize lignite coal with the production of an extracellular peroxidase. They also concluded that solubilization was accompanied by increased hydrophilicity and depolymerization, although little data was supplied to support this conclusion.

Wondrack et al. 39,40 were the first to clearly demonstrate depolymerization of water-soluble lignite and subbituminous coals, which were depolymerized upon incubation with the lignin peroxidase of Phanerochaete chrysosporium (ATCC-34561). They based their conciusions on gel permeation, high performance liquid chromatography in which the average molecular weights of the soluble coal polymers incubated with peroxidase were reduced as compared to the control. While the accuracy of their gelpermeation procedure has recently been questioned (see chapter $3)^{11}$ their data is neverthless fairly conclusive. Addition of veratryl alcohol to the reaction mixture stimulated depolymerization of the coal polymer, and veratryl alcohol oxidation by the peroxidase was inhibited by the coal polymer. 
According to the authors, binding of coal polymer to the peroxidase might be responstble for inhibiting veratryl alcohol oxidation. However, very recent data indicate that veratryl alcohol might act as a third substrate (with $\mathrm{H}_{2} \mathrm{O}_{2}$ ana a primary substrate such as coal) in the lignin peroxidase cycle during oxidation of the pximary substrate. 4 I The papers discused above are largely concerned with solubilization of coal, not depolymerization. However, it is clear from the limited data thus are published that solubilization of coals by fungi is sometimes accompanied by its depolymerization as well.

In 1964, Korburger ${ }^{16}$ was the first to report the utilization of hydrogen peroxide-pretreated coal by bacterial cultures of Escherichia freundi and Pseudomonas rathonis. Fakousa and Truper 18 later isolated a strain of pseudomonas fluorescens arom a mixed popilation collected in a burned forest region. The isolated organism could solubizize coal by the combined action of a bacterial surfactant and an extraceliular enzyme produced by the organism.

In this research 43 we isolated several Iignin-degrading streptomyces species, including s.viridosporous $77 A, s$. setonii $75 \mathrm{Viz}$, and $S$. badius 252. According to crawford and crawford, 58 degradation of lignin by these streptomyces involved oxidative dopolymerization of the lignin polymer. The structural similarity between Ifgnin and lignite prompted an investigation of the conl-solubilizing ability of these streptomyces species. strandberg and Lewis 45 reported that $s$, setonil $75 V i 2$ and $s$.

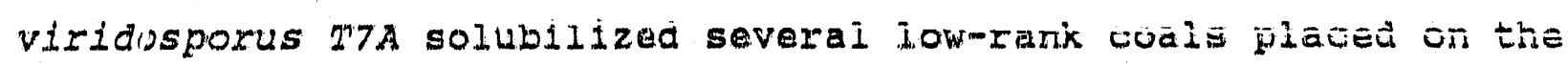


surface of the agar cultures. They observed an extracellular coal-solubilizing component in culture supernatants of coalcontaining submerged cultures of $s$. setonii $75 \mathrm{Vi2}$, but not in cultures of S.viridosporous T7A, 46,47 The solubilizing component was heat stable, protease res" -ant, and had a molecular weight between 1000 and 10,000 daltons. They concluded that the activity was non-enzymatic and ind -ated the possible involvement of basic polypeptide or polyamine. No attempt was made to determine if the soluble product had been depolymerized. We 48 also studied the coal-solubilizing ability of $s$. viridosporous T7A, S. setonii 75Vi2, and $s$. badius 252. After studying the chemical characteristics of the biosolubilized product and examining the mechanism of coal solubilization, we confirmed the involvement of a non-enzymatic mechanism mediated by a microbially-generated basic metabolite.

Initially we isolated the Gram negative bacterium Pseudomonas cepacia DLC-07 from Gasoyne soil (North Dakota) by enrichment in a nineral salts-coal polymer minimal medium over a period of several weeks. 55 This strain grew on water-soluble coal and depolymerized its macromolecular structure. Bacterial depolymerization was monitored by bigh performance liquid chromatograph (HPLC). P. cepacia DLC-07 was able to cometabolize a number of coal model compounds and also utilized phydroxy sibstituted benzoic or cinnamic acids or aldehydes as a sole carbon and energy source.55 cepacia DLC-07-mediated coal depolymerization was non-oxidative as shown by elemental analysis, ${ }^{13} \mathrm{C}-\mathrm{CP} / \mathrm{MAS}$ NMR, and IR data. 55 Later, tried to 
increase the level of coal depolymerization by the addition of a rich carbon source like Sabouraud Dextrose Broth (SDB) or Peptone broth to the medium. We also sometimes supplemented the media with coal-substructure model compounds to act as potential inducers of coal-degrading enzymes. Interestingly, $P$. cepacia DLC-07 depolymerized coal best in peptone+coal broth. 56 The results clearly indicated a decrease in carbonyl content (ester and carboxylate groups), aromatic and conjugated caibon-carbon double bonds, methylene bridges, and etheric oxygen in the depolymerized coal product as compared to the starting coal.

In addition to F. cepacia DLC-07, we isolated four other aerobic bacterial strains from the water-soluble coal polymer minimal medium enrichments. 57,58 one of the bacteria in this group was a Gram positive spore-forming non-motile rod, while the other three were Gram negative rods. The Gram positive bacterium was identified as Bacillus megaterium DLC-21, on the basis of biochemical tests and a gas chromatographic analysis of its cellular fatty acids. The three Gram negative bacteria were strict aerobes; DLC-62 and DLC-BB2 were both highly-motile rods, while DLC-63/9 was a very long and thin non-motile rod. The biochemical tests and cellular lipid analyses did not lead to their identification; it is certain, hower ar, that DLC-62 is a Pseudomonas.

In order to increase the level of coal depolymerization by these bacteria, and to understand the enzymatic mechanisms involved, we grew the cultures in phosphate buffer-peptone broth containing water-soluble coal as a co-substrate.57,58 Samples 
were taken out at time 0,3 days, and thereafter at intervals of every 3 days for a total of 30 days. The 3 -day old cultures showed excellent coal depolymerization. coal depolymerization was clearly evident in all the bacterial cultures, including $P$. cepacia DLC-07, Bacillus megaterium DLC-21, Pseudomonas sp. DLC62, and the unidentified strains DLC-63/9 and DLC-BB2.

Depolymerized coal was recovered from 3-day old control and inoculated cultures and then analyzed by FT-IR spectroscopy. The coal, although depolymerized, did not show increased oxidation relative to the control coal; this was clearly evident from I.R. difference spectra of all the samples. The difference spectra showed a decrease in carbonyl groups due to un-conjugated ketone and carboxyl groups and _,B-unsaturated esters (1707-1719 $\mathrm{cm}^{-1}$ ), and a decrease in carboxyl groups in conjugation with aromatic rings, hydrogen bonded quinones or highly conjugated carbonyl groups $\left(1666-1637 \mathrm{~cm}^{-1}\right)$. The other weak residual bands at 15251531, $1478,1431,1365$, and $1225-1237 \mathrm{~cm}^{-1} \cdot$ could be due to carboxylates or $c-0$ bonds in phenols or aryl-ethers.58,60 overall the results were indicative of a non-oxidative transformation of the coal polymer.

To investigate the long-worm transformations of watersoluble coal polymer by these strains, Vermont lignite coal samples from a noninoculated control and from inoculated cultures incubated for five months in a minimal-mineral-salts+coal broth, were analyzed for their elemental composition, by FT-IR, and by ${ }^{13} \mathrm{C}$ (CP/MAS) NMR. The overall results showed that the long-term 
coal biotransformations of coal by these cultures involved nonoxidative reaction mechanisms.

Having seen the depolymerizing activity by these five organisms, we wondered just how catabolically versatile they were. We therefore, investigated the co-metabolizability of a number of coal substructure model compounds by these organisms. The co-metabolizing ability of Pseudomonas cepacia DLC-07, (published earlier) 55 and the results from Bacillus megaterium DLC-21, Pseudomonas sp. DLC-62. strains DLC-63/9 and DLC-BB2 are presented in chapter-4.60 sacillus megaterium DLC-21 and Pseudomonas sp. DLC-62 could metabolize p-Hydroxycinnamic acid derivatives (p-coumaric acid, ferulic acid, caffeic acid and 3,4dihydroxycinnamic acid) but none of the four cultures metabolized cinnamic acid. strain DLC-62 was able to metabolize pHydroxybenzoic acid and p-Hydroxybenzaldehyde derivatives except syringic acid. All the four organisms (DLC-21,62,63/9 and DLCBB2) metabolized vanillin and 3,4-Dihyaroxybenzaldehyde, but syringaldehyde (a p-hydroxy derivative of benzaldehyde) was metabolized only by strains DLC-62 and DLC-63/9. Bacillus megaterium DLC-21. was the only organisin to metabolize dibenzothiophene. Two of the organisms (DLC-62 and DLC-BB2) metabolized 8-Hydroxyquinoline. These results clearly demonstrate the catabolic versatility of these organisms. 60

since all five bacterial cultures depolymerized watersoluble coal, we investigated the effect of these cultures when incubated on coal together as a single mixed culture. The reason for doing such an experiment was to determine if these co- 
cultures cuuld depolymerize and modify water-soluble coal by functioning either in sequence or synergistically. After an incubation period of five-months in a minimal mineral-saltstcoal broth, a coal sample from this consortium was analyzed and compared with the other previously characterized coal samples. The results were comparable to individual cultures.

To better understand the mechanism of depolymerization and the nature of the biocatalysts involved in coal depolymerization, we investigated the possibility of depoymerization reactions catalyzed by cell-free culture filtrates. Cell-free culture filterates, from 3-day old cultures grown in mineral saltspeptone broth supplemented with coal polymer, were used to study depolymerizing activity. Water-soluble coal was added to cellfree filtrate and incubated for $4 \mathrm{hr}$. The coal was then precipitated by acidification, dissolved in HPLC solvent, and subjected to size exclusion HPLC. 57 Heat-inactivated filtrates were used as controls; the rest of the procedure was kept the same. The HPLC results with Pseudomonas sp. DLC-62 and DLC-BB2 indicated that an extracellular biocatalyst was responsible for the depolymerizing activity. 60 The HPLC profiles of the control (heat inactivated) and active samples of Pseudomonas sp.DLC-62, clearly show a major peak at a retention time 10.32 corresponding to MW $162,200 \mathrm{D}$. and a shoulder at RT 12.45 (MW 18,200 D) in $4 \mathrm{hr}$ old control sample. Active filtrates on the other hand show two peaks at RT 10.29 and 11.49 corresponding to molecular weights $165,900 \mathrm{D}$ and $47,800 \mathrm{D}$. Sodium borchydride reduction of a $4 \mathrm{hr}$ active cell free filtrate treated-coal fraction showed a major 
peak at $\mathrm{RT} 11.55$ (MW 45,700 D) and a shoulder at RT 10.30 (MW 165,900 D) instead of two major peaks. This kind of behavior strongly suggested that free-radicals were formed during depolymerization of the coal polymer. In the case of strain DLCBB2, active filtrate plus coal incubations after a period of 3 hr, showed two peaks at RT 10.04 (MW 213,800 D) and 11.83 (MW 35,000 D). The heat inactivated control sample, on the other hand showed a sharp peak at RT 9.98 (MW 229,000 D) and a shoulder at RT 11.80 (MW 35,50 n D). The sodium borohydride reduction of the 3 hr fraction leads to a major peak at RT 11.83 (MW 35,000 D) and a shoulder at RT $10.04(\mathrm{MW} 213,800$ D). The results from these two experiments indicated cleavage of macxomolecular bonds which in turn resulted in its depolymerization. The sodium borohydride reduction also indicated the formation of free-radicals, whose existence must be verified by ESR spectroscopy

\section{Future Research Needs}

Additional research is needed to characterize the depolymerization of lignite by these bacteria, particularly with regard to gaining a further understanding of the enzymology involved, and for scaling up the depolymerization process to examine its practical feasibility. Below is a list of the specific research objectives we feel are appropriate for future research.

1. Bench scale ( 1 to 2 liter capacity) three phase sparged slurry bioreactor in batch mode should be used to study the kinetics of bio-depolymerization of lignite by the organisms (Streptomyces viridosporus T7A, Pseudomonas sp. DLC-62, DLC$\mathrm{BB} 2$, and Bacillus megaterium DIC-21). 
2. Low-molecular weight compounds produced in the bioreactors should be separated continuously, fractionated and analyzed by GC/MS and by HPLC/MS. The bio-depolymerized lignite should be characterized by using size-exclusion HPLC, elemental analysis, FT-IR, proton and $13 \mathrm{C}$ (CP/MAS) NMR spectroscopy.

3. The bio-depolymerized lignite should be fractionated by solvent extraction into oils (hexane or pentane soluble), asphaltenes (benzene soluble), pxe-asphaltenes (pyridine soluble), and pyridine insoluble residues. These fractions should then be analyzed for their yields, bulk properties to estimate the relative saturated, monoaromatic, diaromatic, polyaromatic and hetrocyclic compounds, using chromatographic (GC \& HPLC) methods coupled to a mass spectrometer.

4. Using classical enzyme purification techniques, the lignite depolymerses should be isolated and purified from streptomyces viridosporus T7A, Gram negative bacterial strains Pseudomonas $\mathrm{sp}$. DLC-62, DLC-BB2, and Gram positive Bacillus megaterium DLC-2.1.

5. Purified coal depolymerases should be characterized for their etherase, esterase, peroxidase and laccase activities.

6. Optimization of the enzymatic process for lignite depolymerization should be done to ensure optimal substrate concentration, oxygen concentration, temperature, $\mathrm{pH}$, and enzyme to enzyme ratios (if multiple enzymes are involved).

7. From the data obtained above, the correct kinetic parameters and the necessary bioreactor configurations for a pilot scale depolymerization study should be determined.

\section{Materials and Methods Used in This Research}

coal substrates. 55,56 The coal used as a substrate for enrichments was weathered Cuba Alabama lignite which was supplied by Prof. H. Bailey ward (University of Mississippi). This coal was treated with $20 \% \mathrm{HNO}_{3}$, for $6 \mathrm{~h}$. The treated coal was washed, dried, powdered and dissolved in $0.1 \mathrm{~N} \mathrm{NaOH}$, and then the solution was neutralized with $0.1 \mathrm{~N} \mathrm{HCl}$ to $\mathrm{pH} 7.1$ before use. A second polymeric coal substrate, soluble in water at $\mathrm{pH} 5.5$, was prepared from $200 \mathrm{~g}$ of Vermont lignite coal. Powdered lignite was soaked in water for $6 \mathrm{~h}$ and then treated with $20 \% \mathrm{HNO}_{3}$ for 6 
h. This coal was washed, dried, powdered and dissolved in $1 \mathrm{~L} 1 \mathrm{~N}$ $\mathrm{NaOH}$ solution. The solution was centrifuged to remove any undissolved particles, and the supernatant was acidified to $\mathrm{pH}$ 7.0 with dilute HCl. The precipitated coal was centrifuged, washed, dried, and powdered (yield: $100 \mathrm{~g}$ ). The supernatant from the above precipitation was acidified to $\mathrm{pH}$ 5.5. Precipitated coal was recovered by centrifugation, washed ( $\mathrm{pH} 5.5)$, dried, and powdered (yield: $20 \mathrm{~g}$ ). The remaining coal in solution was precipitated at $\mathrm{pH}$ 1.5. The coal was recovered by centrifugation, washed ( $\mathrm{pH}$ 1.5), dried, and powdered (yield: 20 g). The later lignite coal polymer dissolved in solutions of $\mathrm{pH}$ 5.5 or higher and was used as a substrate for coal depolymerization studies.

Nitric acid un-treated Vermont lignite: The procedure was same as above except there was no $\mathrm{HNO}_{3}$ treatment of the coal.

Isolation of Aerobic Bacteria. 55 The bacteria were isolated from soil associated with coal seams and from other soils rich in decomposing plant residues. The enrichment medium contained a mineral salts solution of the following composition $\mathrm{g} / \mathrm{L}:\left(\mathrm{NH}_{4}\right)_{2}$ $\mathrm{SO}_{4}, 2.0 ; \mathrm{KH}_{2} \mathrm{PO}_{4}, 2.0 ; \mathrm{MgSO}_{4}, 0.5 ;$ and $\mathrm{CaCl}_{2}, 0.1$. The medium also contained $0.1 \mathrm{~g} / \mathrm{L}$ yeast extract (Difco, Detroit. MI) and 2.0 $\mathrm{g} / \mathrm{L}$ of soluble Alabama lignite coal. The $\mathrm{pH}$ was adjusted to 5.5 before autoclaving. Soil ( $1 \mathrm{~g}$ ) was added to $100 \mathrm{ml}$ of the medium in a $250 \mathrm{ml}$ flask. Shaking incubation $(250 \mathrm{rpm})$ was for $2 \mathrm{wks}$. at $30^{\circ} \mathrm{C}$. Then, $100 \mu \mathrm{L}$ of the enrichment was transferred to $100 \mathrm{ml}$ of fresh medium, and incubation was continued. After two more such biweekly transfers (a loopful of the inoculum was used in 
the final transfer), pure cultures were isolated by streaking onto Sabouraud Maltose Agar (SMA) plates. Pure colonies were streaked onto agar plates of soluble Vermont lignite coal (2 $\mathrm{g} / \mathrm{L})$-mineral salts medium ( $\mathrm{pH} 5.5)$, and only organisms that showed growth were selected for evaluation. P. cepacia DLC-07 was isolated from Gascoyne soil (North Dakota), Bacillus megaterium DLC-2I from William Loam soil (North Dakota), Pseudomonas sp. DLC-62 \& unidentified gram negative long rod DLC63/9 from Woodland floor soil (Mississippi), and another gram negative strain DLC-BB2 was isolated from organic rich peat soiI (Florida). Stock cultures were maintained on Sabouraud Dextrose Agar (SDA) and on SDA containing $200 \mathrm{ppm}$ soluble coal solution. Cultures are also maintained in minimal mineral salts-soluble coal medium shaking at $30^{\circ} \mathrm{C}$.

Growth of organisms in Minimal Medium containing coal. 55,57 The growth medium contained mineral salts solution as above) and soluble Vermont lignite coal $(2.0 \mathrm{~g} / \mathrm{L}$ dry wt.). In earlier studies $^{55}$ with Pseudomonas cepacia DLC-07, the coal used was $\mathrm{HNO}_{3}$ treated Vermont lignite, while in our latter studies the coal used was $\mathrm{HNO}_{3}$ un-treated Vermont lignite solution. Six 1 liter flasks containing $500 \mathrm{ml}$ of the mineral salts solution (as in isolation of aerobic bacteria above) and soluble Vermont lignite $(2.0 \mathrm{~g} / \mathrm{l})$ were sterilized by autoclaving. One served as an uninoculated control, while others were inoculated separately with a loopful of cells of DLC-07, DLC-21, DLC-62, DLC-63/9, DLCBB2 and a loopful of all of these individual cultures, in the case of mixed cultures. All flasks were incubated with shaking 
$(250 \mathrm{rpm})$ at $30^{\circ} \mathrm{C}$. After a period of five months, a serial dilution plate count was performed on SDA. After five month period the viable cell counts for DLC-07, DLC-21, DLC-62, DLC63/9, DLC-BB2, and DLC-Mix were $1.1 \times 10^{7}, 1.22 \times 10^{3}, 1.08 \times 10^{6}$, $6.8 \times 10^{3}, 6.0 \times 10^{5}$, and $4.3 \times 10^{5}$ cells per $\mathrm{ml}$.

Coal Depolymerization in Peptone Broth. 57 cultures (DLC-07, DLC21, DLC-62, DLC-63/9, DLC-BB2, and DLC-Mix.) were grown in $250 \mathrm{ml}$ of mineral salts-peptone broth $\left(\mathrm{Na}_{2} \mathrm{HPO}_{4}, 4.26 \mathrm{~g} / \mathrm{l} ; \mathrm{KH}_{2} \mathrm{PO}_{4}, 2.65\right.$ $\mathrm{g} / \mathrm{I} ; \mathrm{MgSO}_{4} 200 \mathrm{mg} / \mathrm{I} ; \mathrm{CaCl}_{2}, 20 \mathrm{mg} / \mathrm{l}$; and peptone, $5.0 \mathrm{~g} / \mathrm{I}$; $\mathrm{pH}$ 5.5) supplemented with $100 \mathrm{mg}$ of water soluble coal polymer supplied in $5.0 \mathrm{ml}$ of aqueous solution. The sterile coal solution was added to the autoclaved medium afterwards to avoia coal precipitation and coagulation. For assay of coal transformations, $5 \mathrm{ml}$ of samples were pexiodically $(3 \mathrm{~d}, 6 \mathrm{~d}$ to 30 days at $3 \mathrm{~d}$ intervals) withdrawn, centrifuged, and acidified to $\mathrm{pH}$ 2.0. The precipitated coal from 3 day old samples were collected, washed, and dried for FT-IR analysis. For HPLC analysis, $1 \mathrm{ml}$ of a periodically withdrawn sample from inoculated and un-inoculated flasks was acid precipitated ( $\mathrm{pH} 2.0)$, washed (with water, added very gently from the sides of micro-fuge tubes to avoid any spurting ). The precipitated coal was then redissolved in $1 \mathrm{ml}$ of HPLC solvent and subjected to HIPLC analysis. The $\mathrm{pH}$ values for 3 day old centrifuged sample for Control, DLC-07, DLC-21, DLC-62, DLC-63/9 DLC-BB2 and DLC-Mix. were $5.55,6.24,6.44,5.98,5.59,6.04$, and 6.48 , respectively. 
HPLC Analysis for Molecular Weights Determinations. $55-59$ Coal samples from mineral salts-peptone experiments and from cell fxee extract experiments were analyzed on a Hewlett Packard 1090A high performance liquid chromatograph (HPLC) equipped with an HP-1040A diode array detector and a synchropack GPC-300 column (Synchrom, Inc., Lafayette, IN). The mobile phase consisted of buffer $\left(0.02 \mathrm{M} \mathrm{KH} \mathrm{KH}_{4}\right.$ containing $0.5 \%$ Tween-80, $\left.\mathrm{pH} 7.1\right)$ set at a flow rate of $0.25 \mathrm{ml} / \mathrm{min}$. Elution of the coal polymer was monitored at $254 \mathrm{~nm}$. High and low molecular weight protein standards from Pharmacia were used for plotting a standard curve.

Coal Depolymerization in Cell-Free Extract. 57 culture strains of Pseudomonas sp. DLC-62 and DLC-BB2 were grown for 3 days (250 rpm, and at $30^{\circ} \mathrm{C}$ ) in $250 \mathrm{ml}$ mineral salts-peptone broth, supplemented with $2 \mathrm{mg}$ of water soluble coal polymer as an inducer. Cultures were harvested, and the cells were removed by centrifugation. The supernatant was used as the source of the extracellular coal-depolymerizing enzymes. For the assay, $100 \mu \mathrm{I}$ of soluble coal polymer solution was added to $10 \mathrm{ml}$ of the crude cell-free extract. After 0 and $4 \mathrm{hr}$ incubation $\left(25^{\circ} \mathrm{C}\right)$ the reaction was stopped by acidifying the solution $(1.0 \mathrm{ml})$ to $\mathrm{pH}$ 2.0. The precipitated coal was centrifuged, washed (gently with water), redissolved in $1.0 \mathrm{ml}$ of HPLC solvent, and subjected to HPLC. Controls consisted of reaction mixtures treated similarly, but heat-inactivated (15 min.) supernatant was used as the enzyme source. 
The $4 \mathrm{hr}$ old active cell free extract-coal solution from strain DLC-62 was reduced by adding 2 drops of $1 M$ sodium borohydride solution (To make up, dissolve $0.4 \mathrm{~g} \mathrm{NaOH}$ in $75 \mathrm{ml}$ of water, add $3.86 \mathrm{~g}$ of $\mathrm{NaBH}_{4}$ and stir to dissolve. Dilute the solution to $100 \mathrm{ml}$ with water and filter.), allowed to stand for 5 min., acidified to $\mathrm{pH} 2.0$, and woxked up as above for HPLC analysis. In case of strain DLC-BB2, $3 \mathrm{~h}$ old active cell-free extract-coal fraction was reduced with sodium borohydride solution. coal depolymerization was monitored over time by monitoring of the HPLC elution profiles.

Cometabolism of substructure Model compounds. 55 A loopful of cells from the SDA stock slants of Bacillus megaterium DLC-21, $D L C-62, D L C-63 / 9$, and DLC-BB2 were used to inoculate $5 \mathrm{ml}$ of Sabouraud dextrose broth in big size test tubes. After an incubation of $18-20 \mathrm{~h}$ shaking (250 rpm) at $30^{\circ} \mathrm{C}, 0.5 \mathrm{mg}$ of model compound dissolved in $25 \mu \mathrm{L}$ of dimethylformamide (DMF), was added to the test-tubes and to a corresponding set of uninoculated control. After a period of 7 days cells were removed and the UVvisible spectra of the supernatants were measured. The recordings were made on a Hewlett Packard 8452A Diode Array UV/VIS spectrophotometer.

Elemental Analysis. Elemental analysis of $1-3 \mathrm{mg}$ of control and depolymerized coal samples were performed by Desert Analytics, Inc. (Tucson, AZ), using standard procedures. 
Infrared spectroscopy. FT-IR spectra of coal samples were recorded using Perkin-Elmer 1600 spectrometer. KBr. pellets, which had been well-dried and stored under vacuum, were used for all analyses. Spectra were obtained using $2 \mathrm{mg}$ of coal polymer and $150 \mathrm{mg}$ of $\mathrm{KBr}$. Scans were signal averaged to obtain a primary spectrum in wave numbers 4400 to $450 \mathrm{~cm}^{-1}$.

NMR spectroscopy. The solid state ${ }^{13} \mathrm{C}$ cross-polarization magic angle spinning (CP/MAS) NMR was measured at $75.4 \mathrm{MHz}$ on an IBM NR-300 NMR spectrometer with $0.35 \mathrm{~cm}^{3}$ vol. doty probe (Doty Scientific, Inc., columbia, sc). The pulse width of $90^{\circ}$ was 6 $\mu \mathrm{s}$. A repetition time of $1 \mathrm{~s}, 5 \mathrm{kHz}$ spinning rate, and 36,000 scan time were selected.

Enzyme Assays. Extracellular enzynes (esterases, and peroxidases) will be assayed using methods used in our group over the years. 59,61-64 Naturally occurring products like eugenol methyl ether (4-allylveratrole), asarone (2,4,5-trimethoxy-1propenylbenzene), and safrole (4-allyl-1,2-methylenedioxybenzene) will be used to monitor etherase activity.

Enzyme purification. Combination of techniques including ultrafiltration, ammonium sulfate pwecipitation, gel permeation chromatography, ion exchange chromatography, HPLC, electrophoresis and affinity column chromatography will be used to purify extracellular depolymerizing enzymes. 59, 64-67 


\section{REFERENCES}

1. U.8. Department of Energy, Annual Energy Review 1989, Energy Information Administration, office of Energy Market and End Use, Washington, D.C. DOE/EIA-0384(89).

2. U.s. Department of Energy, clean Coal Technology: The New Coal Era Waohington, D. C. November, 1989. DOE/FE-0149.

3. Frank, H. G., and stadelhofer, J. N., Industrial Aromatic Chemistry: Raw materials, Processes, and Products, springerVerlag, Berlin, $1988,31$.

4. Bchobert, H, H., structural features of low-rank coals, Resources Conservation and Recycling, 3, 111, 1990.

5. schobert, H. H., The chemistry of low-rank coals, in ACS Series Number, 234 , American Chemical Society, Washington DC. 1984.

6. Olson, G. J., and Brimkman, P. E., Bioprocessing of coal, Fuel, $65,1638,1986$.

7. Inbister, J. D., Fyza, R. Z., Lippold, A. D., and Anspach, G., Bioprocessing of coal, in Envrironmental Biotechnology, omenn, G.S., Eds., Plenum Press, New York, 1988, 281.

8. Srivastava, R. D., Cambell, I. M., and Blaustoin, B. D., Coal bioprocessing: A research-needs assessment, Chem. Eng. Progress, 45, 1989.

9. Haggin, J., Applications of biotechnology to fossil fuels explored, Chom. Eng. News, 13, 28, 1989.

10. Wise, D. I., Bioprocessing and biotreatment of coal, Mercel Dekjer Inc. New York, 1990.

11. Crawford, D. I., (Ed.) Microbial Transformations of Low Rank coals, CRC Press Inc., Boca Raton, Florida, in press, 1992.

12. Potter, M,C., Bacteria as agents in the oxidation of amorphous carbon, in Proc. $R$. Soc. London, Ser. $B$, $80,239,1908$.

1.7. schroder, H., The bacterial content of coal, zentralbl. Bakteriol. Parasitenk, 41, 460, 1914.

14. Fisher, F., Fucha, W., ther das wachstum von Pilzen auf Kohl, Brennst. Chell., 8, 293, 1927.

15. Rogoff, M. H., Wender, I., and Anderson, R. B., Microbiology of coal, information circular 8075, U.S. Bureau of Mines, Wasinington, D.C. İ́̃a. 
16. Rorburger, J. A., Microbiology of coal : growth of bacteria in plain and oxidized coal slurries, in Pro. W. Va. Acad. Sci., 36, 26, 1964 .

17. Fakoussa, R. M., Coal as a substrate for microorganisms: Investigations of the microbial decomposition of untreated hard coals. Ph.D. thesis, Fredrich-wilhelm Universitä, Bonn, 1981.

18. Fakoussa, R. M., and Trüper, H. G., Coal as a microbial substrate under aerobic conditions, translation from, Kolloquium in der Bergbau-Forschung, GmbH, Biotechnologie im steinkholenbergbau, Essen, W. germany, 41, 1983.

19. Cohen, M. S., and Gabriele, R. D., Degradation of coal by the fungi polyporous versicolor and Poria monticola, Appl. Environ. Microbiol. 44, 23, 1982.

20. Ward, B., Lignite degrading fungi isolated from a weathered outcrop, Syst. Appl. Microbiol. 6, 236, 1985.

21. Ward, B., Apparent liquefaction of ilgnite by fungi and their growth on lignite components, in Froc. Bioenergy, 84 world conference and exhibition, Egneus, E.E., and Ellegard, a., Eds., Biomass Conv. 1985, 3.

22. Ward, B., and sanders, A., Solubilization of lignites by fungi, in Proc. 1989, Symp. on Biological Processing of Coal and Coal-Derived Substances, Electric Power Res. Ins. Palo Alto, CA. , 3-57, $1989 .$.

23. scott, C. D., strandberg, G. M. and Lewis, s. N., Microbial solubilization of coal, Biotechnol. Prog. 2, 131, 1986.

24. scott, C D., Lewis, 8. N., Biological solubilization of coal using both in vivo and in vitro processes, Appl. Biochem. Biotechnol. 18, 403, 1988.

25. Wilson, B. W., Bean, R.M., Rranz, J. A., Thomas, B. L., Cohen, M. S., Aronson, H., and Gray, E. T.. Jx., Microbial conversion of low-rank coal: Characterization of biodegraded product, Energy and Fuels, 1, 80, 1987.

26. Cohen, 8., Bowers, W.C., Mronson, H., and Gray, E. T., Jr., cell free solubilization of leonardite by an extracellular fraction from Polyporus versicolor, Appl. Environ. Microbiol. 53, 2840, 1987

27. Pyne, J. W., stewart, D.1., Iredrickson, J., and Wilson, B. W., Solubilization of leonardite by an extracellular fraction from Coriolous versicolor, Appl. Environ. Microbiol. 53, 2844, 1987. 
28. Bean, R. M., Microbial Conversion of Coal, in Final Report, October 1989, Project 8003-5, EPRI GS-6553, Electric Power Res. Inst. Palo Alto, CA. October, 1989.

29. Maka, A., srivastava, V. J., Kilbane, J. J.. II., and Akin, c. Biological solubilization of untreated North Dakota lignite by a mixed bacterial / fungal culture, Appl. Biochem. Biotechnol. 20/21, 715, 1989.

30. Fredrickson, J. K., stewart, D. I., Cambell, J. A., Powel1, M. A., McKullock, M., Pyne, J. W., and Bean, R. M., Biosolubilization of low-rank coal by a Trametes versicolor siderophore-like product and other complexing agents, $J$. Ind. Microbiol. 5, 401, 1990.

31. Cohen, M. B., Feldman, K. A., Brown, C. B., and Gray, E. T., Jr., Isolation and identification of the coal-solubilizing agent produced by Trametes versicolor, Appl. Environ. Microbiol. 56, 3285, 1990.

32. Faison, B. D., and Lewis, B. N., Production of coal solubilizing activity by Paeciliomyces sp. during submerged growth in defined liquid media., Appl. Biochem. Biotechnol. $20 / 21,743,1989$.

33. Davidson, B. H., Nicklaus, D. M., Moodward, C. A., Lewis, S. N., and Faison, B. D., Characterization and subsequent utilization of microbially solubilized coal: preliminary results, in proc. 1989. symp. on biological processing of coal and coal derived substances, Electric power Res. Ins. palo Alto, CA., 1989, 3-43.

34. Faison, B. D., Foodward, C. A., and Bean, R. M., Microbial solubilization of a peroxidized subbituminous coal, App. . Biochem. Biotechnol. 24/24, 831, 1990.

35. Pechurkin, N. B.; Popova, I. Y., Tushkova, G. I., Furyaeva, A. F., Marchenkova, T. V., and Andreeva, I. V., Growth and development conditions of mixed yeast culture on brown coal, Biotekhnologiya, 5, 40, 1990 .

36. Innehan, J. c., characterization of the coal biosolubilization process using gel permeation chromatography and CP/MAS NMR, In Proc. First International symp. on Biological processing of Coal, Electric power Res. Inst. Palo Alto, CA. I-73. 1990.

37. Stewart, D. L., Thomas, B. L., Bean, R. M., and Fredrickson, J. R., Colonization and degradation of oxidized bituminous and lignite coals by fungi, J. Ind. Microbiol. , 53, 1990.

38. Fakoussa, R. M., and Willmann, G., Biochernical and enzymatic studies of the active compounds in soiubilizationjifuguefaction of hard coale and Iignite, $\mathrm{E}$, 
In Proc. First International symp. on Biological Processing of Coal, Electric Power Res. Inst. Palo Alto, CA., 1990, 41 .

39. Wondrack, I., Bzanto, M., and Wood, W. A., Depolymerization of water soluble coal polymer from subbituminous and lignite by lignin peroxidase, Appl. Biochem. Biotechnol. 20/21, 765, 1989.

40. Wood, W. A., Wondrack, L. M., Enzymatic depolymerization of coal, US Patent, 4960699,1990.

41. Paszczynski, A., and Crawford, R. L., Degradation of azo compounds by ligninase from phanerochaete chrysosporium: involvement of veratryl alcohol, submitted to Biochem. Biophys. Res. Commun. 1991.

42. Iindqvist, I., Charge transfer interaction in a humic acid, Acta Chem. Scand., B 4I, 476, 1987.

43. Crawford, D. I., Pometto, A. I., III., and Deobald, I. A., The pathway of lignin degradation by streptomyces: Chemistry and enzymology, in Recent advances in lignin biodegradation research, Higuchi, H. M., Chang, H. M., and Kirk, T. K., Eds., UNI Pulishers, Tokyo, 1983, 78.

44. Crawford, D. I., and crawford, R. L., Recent advances in studies on the mechanisms of microbial degradation of lignins, Enzyme, Microb. Technol. 6, 434, 1984.

45. Strandberg, G. W., and Lewis, 8. N., Solubilization of coal by an extracellular product from streptomyces setonii 75Vi2, J. Ind. Microbiol. 1, 371, 1987.

46. Strandberg, G. W., and Leris, 8. N., Factors affecting coal solubilization by the bacterium streptomyces setonii $75 \mathrm{Vi2}$ and by alkaline buffers, Appl. Biochem.Biotechnol. 18, 355, 1988 .

47. strandberg, G. W., and Lewis, s. N., Microbial solubilization of coal, US Patent, 4914024,1990.

48. Gupta, R. R., spiker, J. R., and crawford, D. I., Biotransformation of coal by lignolytic streptomyces. Can. J. Microbiol. 34, 667,1988.

49. Quigley, D. R., Fard, B., Crawford, D. L., Hatcher, H. J. and Dugan, $\mathbf{P}$. $R_{0}$, Evidence that microbially produced alkaline materials are involved in coal biosolubilzation, Appl. Biochem. Biotechnol. 20/21, 753, 1989. 
50. Hoolick, R. T., Iinden, J. C., and Rarim, M. N., Biosolubilization of lignite, Appl. Biochem. Biotecnol. $20 / 21,731,1989$.

51. Catcheside, D. E. A., and Mallett, R. J., Solubilization of Australian lignites by fungi and other microorganisms, Energy and Fuels, 5, 141, 1991.

52. Ralph, J. P., and Catcheside, D. E. A., Nutritional versatility of microorganisms able to utilize lignite as their sole carbon source, in in Proc. Second International symposium on the Biological Processing of Coal, Electric Power Res. Institute, Palo Alto, CA., EPRI GS-7482, 4-55, 1991.

53. Polman, J..R., Breckenridge, C. R., and quigley, D. R., Degradation of lignite coal by bacteria, in in Proc. Second International symposium on the Biological processing of Coal, Electric Power Res. Institute, Palo Alto, CA., EPRI GS-7482, P-63, 1991.

54. Runnion, R., and Combie, J. D., Thermophilic microorganisms for coal biosolubilization, Appl. Biochem. Biotechnol. $25 / 25,817,1990$.

55. Gupta, R. $\mathbb{R}_{,}$, Deobald, I. A., and crawford, D. I., Depolymerization and chemical modification of lignite coal by Pseudomonas cepacia strain DLC-07, Appl. Biochem. Biotechnol. 24/25, 899, 1990.

56. Crawford, D. I., Gupta, R. R., Influence of cultural parameters on the depolymerization of a soluble lignite coal polymer by Pseudomonas cepacia DLC-07, Resources, Recycling, and Conservation, 5, 245, 1991.

57. Crawford, D. I., Gupta, R. R., Deobald, L. A., Roberts, D. $J$., Biotransformation of coal and coal substructure model compounds under aerobic and anaerobic conditions, in Proc.: 1990 First Int. Symp. on the Biological processing of coal, Electric Power Res. Institute, Palo Alto, CA. 1990, 4-29.

58. Crawford, D. I., Gupta, R. R., Characterization of extracellular bacterial enzymes which depolymerize a soluble coal polymer, Fuel, 70, 577, 1991.

59. Roberts, M. A., and Crawtord, D. I., Peroxidase and esterase production by coal depolymerizing Pseudomonas strain DLC-62, in Proc. Second International symposium on the Biological Processing of Coal, Electric Power Res. Institute, Palo Alto, CA., EPRI GS-7482, 4-5, 1991 .

60. Crawford, D. I., and Gupta, R. K., Microbial depolymerization of coal, in Microbial Transformation of Low 
Rank Coals, Crawford, D. L., Ed., CRC Press Inc., Boca Raton, Florida, chap. 4, in press, 1992.

61. Donnelly, R. R., and Crawford, D. I., Production by streptomyces viridosporous T7A of an enzyme which cleaves aromatic acids from lignocellulose, Appl. Environ. Microbiol. 54, 2237, 1988.

62. Deobald, I. A., and crawford, D. I., Activities on cellulase and other extracellular enzymes during lignin solubilization by streptomyces viridosporous. Appl. Microbiol. Biotechnol. $26,158,1987$.

63. Ramachandra, M., Crawford, D. L., and Hertel, G., Characterization of an extracellular lignin peroxidase of the lignocellulolytic actinomycete streptomyces viridosporus, Appl. Environ. Microbiol. 54, 3057, 1988.

64. Pasti, M. B., Pometto III, A. I., Nuti, M. P., and crawford, D. L., Lignin solubilizing ability of actinomycetes isolated from termite (termitidae) gut, Appl. Environ. Microbiol. 56, 2213,1990 .

65. Schulz, G. E., and schirmer, R. H., Principles of protein structure, Springer-Verlag, Berlin, 1979.

66. Homes, B. D., Gel electrophoresis of proteins-A practical approach, Oxford: IRL Press, 1-91, 1981.

67. Pharmacia, Affinity Chromatograpy, principles and methods, Pharmacia, Uppasala (Sweden), 1986. 


\section{Papers and Presentations Resulting From This Research}

\section{Papers Published}

1) Gupta, R. J., J. K. Spiker, and D. L. Crawford. 1988. Biotransformation of coal by lignino-lytic streptomyces. Can. J. Microbiol. 34:667-674.

2) Quigley, D. R., H. B. Ward, D. L. Crawford, J. C. Weh, H. L. C. Meuzelaar, H. J. Hatcher, and P. R. Dugan. 1989. Evidence that nicrobially produced alkaline materials are involved in coal biosolubilization. Appl. Biochem. Biotechnol. 20/21:753-763.

3) Gupta, R. K., L. A. Deobald, and D. L. Crawford. 1989. Depolymerization and chemical modification of lignite coal by Pseudomonas cepacia strain DLC-07. Appl. Biochem. Biotechnol. 24/25:899-911.

4) Crawford, D. L. and R. K. Gupta. 1990. Influence of cultural parameters on the depolymerization of a soluble lignite coal polymer by Pseudomonas cepacia DLC-07. Resour. Conserv. Recycl. 5: $245-254$.

5) Gupta, R. K. and D. L. Crawford. 1990. Oxidation of dibenzothiophene by Cunning-hamella elegans. Curr. Microbiol. $21: 229-231$.

6) Crawford, D. L., R. K. Gupta, L. A. Deobald, and D. J. Roberts. 1990. Biotransformations of coal and coal substructure model compounds by bacteria uncier aerobic and anaerobic condjtions, p. 4-28 to 4-43. Proc. 1st Intl. Symp. Biological Processing of coal, Electric Power Research Inst., Palo Alto, CA.

7) Crawford, D. I., R. K. Gupta, and L. A. Deobald. 1991. Characterization of extracellular bacterial enzymes which depolymerize a soluble lignite coal polymer. Fuel 70: 577-580.

\section{presentations}

1) Quigley, D. R., H. B. Ward, D. L. Crawford, J. C. Yeh, H. L. C. Meuzelaar, H. J. Hatcher, and P. R. Dugan. 1988. Evidence that microbially produced alkaline materials are in-volved in coal biosolubilization. Presented, Tenth Symp. on Biotechnology for Fuels and Chemicals. Gatlinburg, TN. May 16-20. 
2) Gupta, R. K., I. A. Deobald, and D. L. Crawford. 1989. Depolymerization and chemical modification of lignite coal by Pseudomonas cepacia strain DLC-07. Presented, Eleventh Symp. on Biotechnology for Fuels and Chemicals, Colorado Springs, Co. May 8-12.

3) Crawford, D. L. and R. K. Gupta. 1989. Influence of cultural parameters on the depolymerization of a soluble lignite coal polymer by Pseudomonas cepacia DLC-07. Presented, Bioprocessing of Fossil Fuels Symp., Tyson's Corner, VA.Aug.8-10.

4) Deobald, L. A. and D. 1. Crawford. 1989. Isolation of microorganisms able to reductively transform aromatic compounds and their relevance to coal liquefaction. Presented, Institute of Gas Technology second Intl. Symp. on Gas, Oil, Coal, and Environmental Biotechnology. New orleans, IA. Dec. 11-13.

5) Crawford, D. L., R. K. Gupta, L. A. Deobald, and D. J. Roberts. 1990. Biotransformations of coal and coal substructure model compounds by bacteria under aerobic and anaerobic conditions. Presented, First Intl. Symp. on the Biological Processing of Coal, orlando, FL. May $1-3$.

6) Crawford, D. I. 1990. Characterization of extracellular bacterial enzymes which depolymerize a lignite coal polymer. presented, symp. Biotechnology for the production of clean fuels. Am. Chem. Soc., Fuels Div., Washington, D.C. Aug. 26-31.

7) Roberts, M.A. and D.L. Crawford. 1991. Iignite coal depolymerizing enzymes from bacteria. Presented, Int'l. Symp. on the Biological processing of Coal. sponsored by Eletric power Research Institute (EPRI), San Diego, CA. May 1-3.

8) Roberts, M. and D.L. Crawford. 1992. Esterase and peroxidase production by coal depolymerizing Pseudomonas strain DLC-62. To be Presented, 92nd Gen. Meeting Amer. Soc. for Microbiol. May. New orleans, LA. 

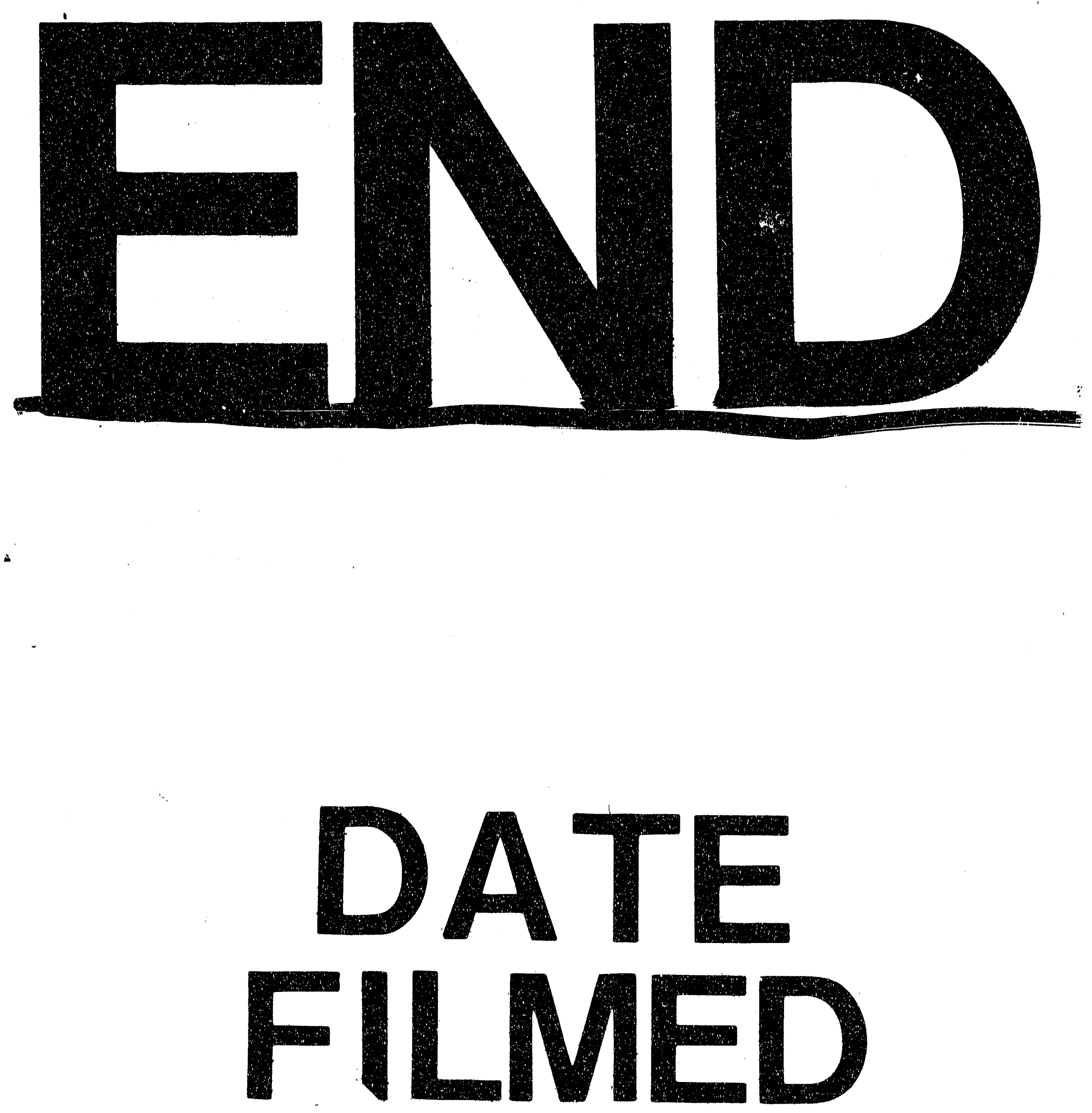

要

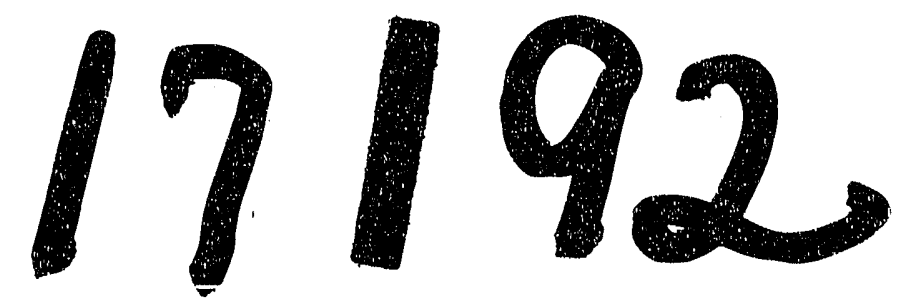


1 